\title{
REARING OF TRILOBED MALE UNCUS OSTRINIA SPECIES IN LABORATORY FOR EXPERIMENTAL PURPOSES
}

\author{
A.N. Frolov*, M.N. Berim, I.V. Grushevaya \\ All-Russian Institute of Plant Protection, St. Petersburg, Russia
}

corresponding author,e-mail: vizrspb@email.ru

\begin{abstract}
Insect rearing on artificial diets allows to solve a wide range of entomological tasks. During decades passed after publication of the pioneer paper written by G. Bottger (1942) devoted to cultivation of the European corn borer, Ostrinia nubilalis, a lot of diets have been developed both for laboratory and mass rearing of insects. The paper briefly reviews published material dedicated to technique of rearing harmful Ostrinia species in the world as well as contains detailed description of procedures used in All-Russian Institute of Plant Protection for rearing the European corn borer, O. nubilalis, the Asian corn borer, O. furnacalis and adzuki bean borer, $O$. scapulalis on the basis of the universal diet including mix of wheat germs, soybean and corn flour. The paper describes rearing details of Ostrinia representatives providing live material of a various genetic origin which exhibit reactions statistically indistinguishable from those displayed by individuals taken from nature.
\end{abstract}

Key words: corn borer, artificial nutrient medium, laboratory rearing

Design of technologies of laboratory and large-scale rearing of agricultural pests is an important task of technical entomology (Tamarina, 1990). Insect rearing on artificial diets has the purpose to solve a wide range of theoretical and applied tasks (Zlotin, 1989). During decades passed after publication of the pioneer paper written by G. Bottger (1942) devoted to rearing of the European corn borer, Ostrinia nubilalis, a lot of diets have been developed both for laboratory and mass cultivation of insects (Singh, 1977; Singh, Moore, 1985; Cohen, 2015). However, when using these diets, it is necessary to take into consideration specific alimentary needs displayed by closely related species or even intra-specific forms (Edelman, 1972).

Species group of the genus Ostrinia (Lepidoptera, Crambidae) with male trilobed uncus includes a number of dangerous agricultural pests, such as European corn borer Ostrinia nubilalis (Hübner), Asian corn borer O. furnacalis (Guenée) and adzuki bean borer $O$. scapulalis (Walker) (Mutuura, Munroe, 1970). These species are different in their spreading as well as in ranges of preferred host plants (Frolov, 1993). The European corn borer, widely distributed in Europe and introduced into North America and North Africa, is acknowledged above all as a pest of maize, millet and sorghum (Brindley, Dicke, 1963). Maize is also a primary damaged plant by Asian corn borer but the host range for this species is remarkably broader (Wang et al., 2000). Spreading of adzuki bean borer is largely overlapped with ranges of $O$. nubilalis in Europe and O. scapulalis in Asia. In contrast to the latter two species, however, O. scapulalis damages neither maize, nor other large-stem cereals, being an important pest of hemp and hop (Frolov, 1984; Ishikawa et al., 1999).

The European and Asian corn borers as well as the allied species of the genus Ostrinia have acquired status of rather popular model objects to examine diverse topics of insect evolutionary ecology, including formation of trophic interactions with host plants, establishment and maintenance of relations in systems "insects - microorganisms", evolution of pheromone communication, etc (Frolov, 1994; Lassance, 2010). Accordingly, rearing of these insects is important not only for utilitarian purposes, such as supplying trials in plant resistance to pests or toxicity assays with live material (Shapiro et al., 1980; Mihm, 1985; Georgescu et al., 2017). Thorough scientific investigations, in which the insect is the primary object of the research, need adequate quality of insects as well. Goal of the present work is to review briefly the publications devoted to rearing of representative of the genus Ostrinia, and to describe technological approaches used in All-Russian Institute of Plant Protection (VIZR) for insect cultivation as live material for scientific purposes.

Different ways of sampling of live insects in nature are given in the literature to provide starting material for the stock cultures, from collection of eggs on host plants (e.g., Hirai, Legacion, 1985) to capture of gravid female adults (e.g., Win, Ishikawa, 2015). Among other methods, collection of diapausing larvae is considered more appropriate due to the following benefits: 1) high searching efficacy in nature as damaged plants are well-seen; 2) simplicity of storage; 3) ability to initiate the research in a desired timeframe after the necessary period of hibernation (Khomyakova, 1971; Beck, 1985). In Ostrinia spp. the diapause termination needs a period of certain longevity for keeping larvae under low temperatures. Insect reactivation should not therefore be started before the beginning of March as increased mortality rate and extended pupation timeframe is expected. Basing upon these considerations, the larvae collected in the autumn which have stopped their feeding completely and entered the diapause are used as the initial starting material (Shapiro et al., 1980).

Insect collection is being performed on the preferred host plant (depending upon the species): maize in European (Northern Caucasus, Central Black-Earth ("Chernozem") Region) and Asian parts of Russia (Far East from Amur Region to Primorye) in case of $O$. nubilalis and O. furnacalis, respectively. When $O$. scapulalis is needed, dicotyledonous plants are to be chosen, including hemp and hop among the crops and mugwort and cocklebur among the weeds. These plants should not be taken in vicinity to maize, millet and sorghum stands to exclude contamination of samplings with 
O. nubilalis or O. furnacalis larvae (Frolov, 1991). Species identity is clarified using male morphology according to Frolov et al., 2007). When the collected insects are abundant, risks of mass infection by insect pathogens is minimal and the rearing is solely for applied (technical) needs, storage of hibernating larvae within the stems is acceptable. Then the collected plants with evident signs of larval damage (indicating insect presence) are maintained during the winter under nature-like conditions (Georgescu et al., 2015).

When the final goal of insect cultivation is scientific research, this is advisable to recover hibernating larvae from the stems during sampling and to place them into glass vials (preferred over plastic as its toxicity, depending upon chemical composition, may be deteriorating to the larvae expressing gnawing activity even without feeding). Not more than 40 specimens should be placed per $0.5 \mathrm{~L}$ vials. Paper sheets $(180$ $\mathrm{g} / \mathrm{cm}^{2}$ ) folded into several layers are inserted into the vials so that the larvae weave loose cocoons as a hideout during hibernation. Plastic caps with small holes for ventilation are used to cap the vials. After several days of incubation at RT (needed for the cocoon formation), the insects are placed to a refrigerator at $+0-4{ }^{\circ} \mathrm{C}$ prior to diapause termination.

For reactivation, vials with larvae are removed to a thermostat and the temperature is gradually increased up to $+26-28^{\circ} \mathrm{C}$ during $2-3$ days. For pupation, insect need thorough moistening and the vial contents are to be soaked in tap water and the excess liquid is removed, leaving the folded paper completely wet but without layer of water at the bottom of the vial. This procedure is performed at least twice within the first week of diapause termination. Lack of moisture impedes the pupation while excessive moistening (augmented by insufficient ventilation) causes increasing mortality. First pupae are formed after 1-2 weeks of reactivation (depending upon the population) which are to be transferred to separate "emerging" vials for collection of emerging adults. When insect numbers are few, adults may be collected from vials with larvae but the distance between the upper margin of the folded paper and the vial cap must be not less than $5 \mathrm{~cm}$ to provide the space needed to eclosing adults (Frolov, 1984).

Moth maintenance, as well as egg collection and storage for laboratory rearing (under 5000 adults per generation) is described in a number of publications, including Shapiro et al. (1980). Newly emerged adults, 1 or 2 pairs (to keep equal sex ratio) are placed into $0.5 \mathrm{~L}$ glass vials. Cylinders made of paraffined or parchment paper (with smooth surface) are inserted inside the vials as additional walls, serving as a substrate for oviposition. The vial opening is covered with a layer of gauze and a piece of moistened cotton is placed above to provide moths with water. It should be moistened regularly but without excessive watering (which makes moth unable to reproduce). The piece of cotton may be placed inside the vials but this is less desirable as manipulations with insects and control of moistening are hampered, the cotton rapidly becomes dirty due to the contact with moths, it also may touch the paper making it wet and the mold is more likely to develop. If the rearing design descried above is conformed, the first egg masses appear after 2-3 days of setup of vials with moths. Eggs are to be recovered each 3-4 days, before they transit to the "black head" stage (indicating that hatching is nearing and may start within next several hours. In large-scale propagation (over 5000 adults per generation), the use of special devices is advisable for insects handling (Reed et al., 1972; Mihm, 1985; Zhou et al., 1992; Frolov, 2008). At industrial scale (over 15000 adults per generation) the moths have better maintained in $60 \mathrm{~cm}$ high iron wire cages (upper side removable) with bottom size of $30 \times 30 \mathrm{~cm}$ and $5 \mathrm{~mm}$ grid size. Pupae, taken every 5 days from vials with activated larvae, are placed into these cages. The acceptable pupae density is up to 300 insects per cage. The cage is covered from above with a sheet of paraffin paper, parchment paper or transparent film which is fixed with clips. The cages are sprayed with water twice a day and the females lay eggs through the grid onto the sheets which are replaced daily. At lower scale (between 5000 and 15000 adults per generation) the moths can be maintained in tin or glass cylinders $35-40 \mathrm{~cm}$ high with diameter of $20-25$ $\mathrm{cm}$ (80-100 moth pairs per cylinder). The cylinder design for oviposition is similar to that for $0.5 \mathrm{~L}$ glass vials, with paper inside and gauze with cotton on the top. Adults are transferred to another cylinder (to recover paper sheets with eggs) using a special device, a hoover (Fig. 1) which greatly hastens the moth transfer into new containers (Frolov, 1993, 2008).

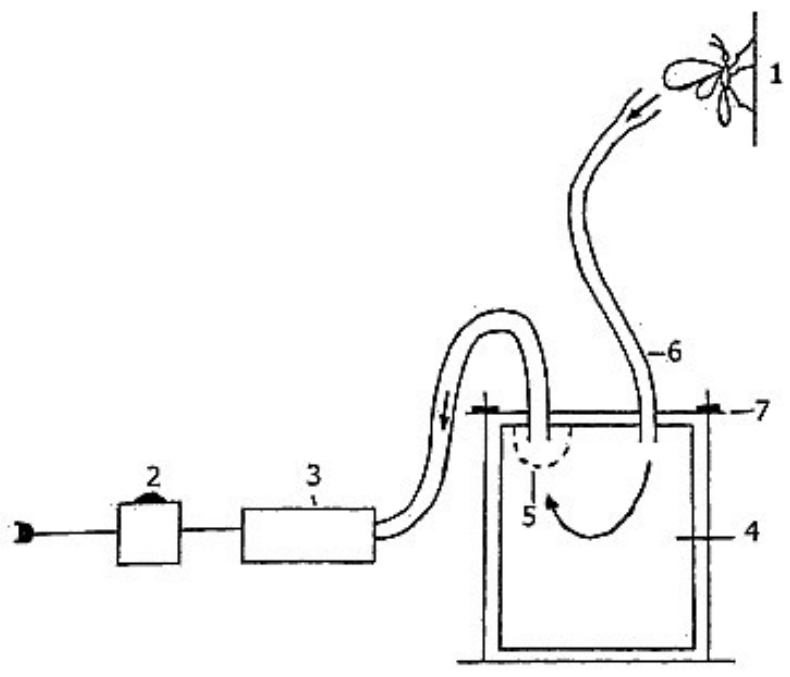

Fig. 1. Principal scheme of the device for transfer of Ostrinia spp. adults. 1 - an adult insect, 2 - a laboratory voltage transformer, 3 - the hoover, 4 - insect recovery box, 5 - safety grid preventing insect uptake by the hoover, 6 - a pipe for insect collection, 7 - upper removable lid.

Arrows indicate air flow direction (Frolov, 2008)

Eggs, laid by the moths on paper or plastic, are placed into Petri dishes and incubated at RT until the "black head" stage. Upper lid of the dish should be regularly moistened to prevent increased egg mortality due to low air humidity. To simplify the manipulations, the paper pieces with egg lays are cut off from the paper sheet. At industrial scale, the thin plastic film is preferable as the egg masses can be easily separated by stretching its opposite side against a metal plate with a sharp edge. Starch is added to avoid eggs clumping. Vial walls are sprayed with distilled water and slight rotation is applied to achieve homogenous distribution of egg lay against the walls without sticking together. The top of the vial is closed with a wet sheet of paper and the egg masses are incubated at RT for 3-4 days. Eggs with larvae ready for hatching may be preserved refrigerated at $+4-5^{\circ} \mathrm{C}$ within a week (Mihm, 1985; Frolov, 1993, 2008). 
As mentioned above, the European corn borer was the first phytophage successfully bred on artificial diet (Bottger, 1942). By now, multiple recipes and modifications have been offered, suitable both for laboratory and industrial rearing (Frolov, Vilkova 1978; Shapiro et al., 1980). The major components are wheat germs (Beck, Stauffer, 1950; Guthrie et al., 1965; Beck et al., 1968; Lewis, Lynch, 1969; Reed et al., 1972; Grisdale, 1973 etc.), dry leaves (George et al., 1960; Nagy, 1970) or seeds of Fabaceae (Salama, 1970; Georgescu et al., 2015, 2017), corn flour (Gahukar, 1975, 1976), and other products of plant origin (Isa, Khadr, 1973). A number of recipes is proposed for Asian corn borer, and wheat germs, bean seeds or corn flour are also the major constituents (Rangdang et al., 1971; Patanakamjorn, et al., 1978; Saito, Nakayama, 1981; Adalla, et al., 1984; Hirai, Legacion, 1985; Zhou et al., 1992; Park, Boo, 1993; Qiao et al., 2008; Rahayu, Trisyono, 2018; Caasi-Lit et al., 2018). In some cases, the research is focused on development of universal diets allowing breeding of a broad range of plant feeding insects (George et al., 1960; Hervet et al., 2016). This increases the importance of quality screening of the live material (Huettel, 1976). Indeed, during industrial and laboratory rearing, different physiological characteristics may change depending upon the diet, as shown on example of O. nubilalis (Dittrick, Chiang, 1981). Long-term continuous rearing on artificial diet may even cause loss of ability of the larvae to develop on maize (Guthrie et al., 1974, 1982, 1984). To preserve the virulence of lab colonies towards maize, one generation of the stock culture needs to be raised on this forage plant after each 8 generations fed on diets (Guthrie, Jarvis, 1989, 1990).

At the All-Russian Institute of Plant Protection, a mixture of corn and soybean flour serves as a major ingredient of the diet for $O$. nubilalis, $O$. furnacalis and $O$. scapulalis. The diet recipe is the result of long-term research of VIZR and Chinese Institute of Plant Protection, Bejing, China (Frolov, Vilkova, 1978; Shapiro et al., 1980; Zhou et al., 1992). To prepare $1 \mathrm{~kg}$ of diet, wheat and soybean flour ( $65 \mathrm{~g}$ each) with addition of 30 $\mathrm{g}$ of wheat germs are thoroughly mixed into $275 \mathrm{~mL}$ of sterile distilled water in $1 \mathrm{~L}$ flask. In another flask of the same volume, $16 \mathrm{~g}$ of microbiological agar $(50 \%$ may be replaced with food agar) are melted in $420 \mathrm{~mL}$ of distilled water using water bath or microwave oven. A smaller flask is used to prepare a mixture of yeast extract ( $48 \mathrm{~g}$ ), vitamins ( $5 \mathrm{~g}$ of ascorbic acid and 8 pills of vitamin complex "Vitrum Kids" by Unifarm or analogue) and antibiotics (1 pill of nistatin, 500000 Units; 1 and $2 \mathrm{~mL}$ of fresh kanamycin and augmentin solutions, respectively, at concentration of $0.1 \mathrm{~g} \mathrm{~mL}^{-1}$ ) in a solution of antiseptic (benzoic acid or sodium parabenzoate, $2 \mathrm{~g}$ per $100 \mathrm{~mL}$ of water). The antiseptic solution is prepared in advance to provide complete dissolving with the use of heating, but the other ingredients of this mixture are not heated. Contents of the jars with flour and boiling agar are mixed together and thoroughly homogenized. After brief cooling of the flour-agar mixture (the agar should not congeal), the contents of the third flask are added and the product is rapidly mixed and poured, while liquid, into the 20 $0.5 \mathrm{~L}$ vials. After the diet is solidified and ambient temperature is established, the vials are closed with caps made of sterile dense cloth, fixed with strings. After evaporation of excessive moisture, the vials are ready for inoculation with egg lays at the "black head" stage at the sterile bench. The eggs may be briefly rinsed with ethanol for surface sterilization which does not affect the viability of hatchlings. As many as 40-60 eggs per $0.5 \mathrm{~L}$ vial are used (Shapiro et al., 1980), on the wet paper pieces which are stick to the glass surface next to the diet layer. The vials are positioned upside-down (bottoms-up) so that the hatched larvae move directly to the diet layer due to the negative geotaxic reaction. The recommended conditions include temperature of $+26-28^{\circ} \mathrm{C}$ and the photoperiod 18:6 hrs. The use of a longer light cycle as compared to common 16:8 hrs (Beck, 1987) is substantiated by induction of diapause under standard photoperiod in northern populations of the pest (Frolov et al., 2016).

The technologies developed by now for insect rearing on artificial diets are aimed at solving a broad scope of technical entomology goals. The procedures of cultivation of Ostrinia described in the present paper allow obtaining live material of a various genetic origin which exhibit reactions statistically indistinguishable from those displayed by individuals taken from nature (Zhukovskaya et al., 2017).

The research is supported by Russian Foundation of Basic Research, grant \# 19-016-00128.

The authors are sincerely grateful to Dr. Yu.S. Tokarev for help with English translation of the article.

\section{References}

Adalla CB, Caasi MT, Legacion DM (1984) Refinement of mass rearing techniques for Asiatic corn borer, Ostrinia furnacalis (Guenee) (Pyraustidae: Lepidoptera). Philipp Agric Sci 67(3):345-349.

Beck SD (1985) Effects of thermoperiod on photoperiodic determination of larval diapause in Ostrinia nubilalis. $J$ Insect Physiol 31(1):41-46.

Beck SD (1987) Developmental and seasonal biology of Ostrinia nubilalis. Agric Zool Rev 2:59-96.

Beck SD, Chippendale GM, Swinton DE (1968) Nutrition of the European corn borer, Ostrinia nubilalis. VI. A larval rearing medium without crude plant fractions. Ann Entomol Soc Amer 61(2):459-462.

Beck SD, Stauffer JF (1950) An aseptic method for rearing European corn borer larvae. J Econ Entomol 43(1):4-6.
Bottger GT (1942) Development of synthetic food media for use in nutrition studies of the European corn borer. J Agric Res 65(10):493-500.

Brindley TA, Dicke FF (1963) Significant developments in European corn borer research. Annu Rev Entomo. 8(1):155-176.

Caasi-Lit MT, Lontoc MBT, Erigbuagas JCS and others (2018) An improved technique for artificial infestation of test insects in bioefficacy studies of Bt corn against the Asian corn borer, Ostrinia furnacalis (Guenee), in the Philippines. Philipp Entomol 31(1):1-14.

Cohen AC (2015) Insect diets: science and technology. 2nd Edition. Boca Raton: CRC Press. 473 p.

Dittrick LE, Chiang HC (1981) Differences in the development response of the European corn borer reared on corn plant vs. meridic diet under greenhouse conditions. Environ Entomol 10(6):889-892. 
Edelman NM (1972) [Mass rearing of phytophagous insects]. In: Itogi nauki i tekhniki. Ser. Entomologiya. M.: VINITI. 1:120-201.

Frolov AN (1984) [Biotaxonomic analysis of harmful species of the genus Ostrinia Hbn.] Ethologiya Nasekomykh, Trudy Vsesoyuznogo Entomologitsheskogo Obshchestva 66:4-100 (In Russian)

Frolov AN (1991) [Analysis of trophic relations of the European corn borer and brush-leg borer (Lepidoptera, Pyraustidae) in the border of the maize field weeded with mugwort]. Ekologiya 3:63-69. (In Russian)

Frolov AN (1993) [Variability of the European corn borer and resistance of maize]. Autoref. Doctor Degree Thesis. Saint Petersburg: All-Russian Plant Protection Institute (VIZR). 41 p. (In Russian)

Frolov AN (1994) [Regularities of the race formation in phytophagous insects: Ostrinia nubilalis (Lepidoptera, Pyralidae), a model]. Zhurnal Obschei Biologii 55(45):464-476. (In Russian)

Frolov AN (2008) [The corn borer]. In: Radchenko EE (ed) Study of genetic resources of grain crops on resistance to harmful organisms. M. Rossel'khozakademiya. p. 282-305. (In Russian)

Frolov AN, Vilkova NA (1978) [Methodical instructions for the study of intrapopulation variability in stem borer owing to host plant specialization]. L. VIZR. 19 p. (In Russian)

Frolov AN, Berim MN, Grushevaya IV and others (2016) [Diapause in Ostrinia nubilalis from northern focus of pest outbreak on maize under long day condition]. Plant Protection News. 4(90):89-91. (In Russian)

Frolov AN, Bourguet D, Ponsard S (2007) Reconsidering the taxomony of several Ostrinia species in the light of reproductive isolation: a tale for Ernst Mayr. Biol J Linn Soc 91(1):49-72.

Gahukar RT (1975) Nouvelles techniques adoptees pour l'elevage d'Ostrinia nubilalis Hubner sur milieu artificiel. Ann Zool Ecol Anim 7(4):491-498.

Gahukar RT (1976) Rearing and biology of Ostrinia nubilalis Hbn. on five artificial diets. Z Angew Entomol 81(1):67-74.

George BW, Raun ES, Peters DC and others (1960) Artificial medium for rearing some Lepidopterous corn insects. $J$ Econ Entomol 53(2):318-319.

Georgescu E, Burcea M, Cana L and others (2015) Technology of the European corn borer (Ostrinia nubilalis Hbn) mass rearing, successive generations, in controlled conditions, at Nardi Fundulea. Bull Uni Agric Sci Vet Med Cluj-Napoca Agric 72(1):113-121.

Georgescu E, Toader M, Balaban N and others (2017) Testing of the new active ingredients for controlling of the Ostrinia nubilalis $\mathrm{Hbn}$ at maize crop, in conditions of artificial infestation, at Nardi Fundulea. Ann Univ Craiova Agric Montanol Cadastre Ser 46(2):121-127.

Grisdale D (1973) Large volume preparation and processing of a synthetic diet for insect rearing. Can Entomol 105(12):1553-1557.

Guthrie WD, Jarvis JL (1989) Recovery of virulence of European corn borer larvae (Lepidoptera: Pyralidae) to damage maize plants after being reared on a meridic diet. $J$ Kans Entomol Soc 62(1):135-137.
Guthrie WD, Raun ES, Dicke FF and others (1965) Laboratory production of European corn borer egg masses. Iowa J Sci 40(1):65-83.

Guthrie WD, Rathore YS, Cox DF and others (1974) European corn borer: virulence on corn plants of larvae reared for different generations on a meridic diet. J Econ Entomol 67(5):605-606.

Guthrie WD, Jarvis JL, Reed GL and others (1982) Plant damage and survival of European corn borer cultures reared for 16 generations on maize plants and for 120 generations on a meridic diet (one generation per year on resistant or susceptible maize plants, eight generations per year on the diet). J Econ Entomol 75(1):134-136.

Guthrie WD, Jarvis JL, Reed GL (1984) Leaf-feeding damage by European corn borer (Lepidoptera: Pyralidae) larvae reared one generation each year on dent maize and eight generations each year on a meridic diet (for eight years) and then reared continuously on a meridic diet for eight additional years. J Kans Entomol Soc 57(2):352-354.

Guthrie WD, Jarvis JL (1990) Plant damage and survival of European corn borer (Lepidoptera: Pyralidae) larvae reared for 22 years on resistant and susceptible inbred lines of maize. J Kans Entomol Soc 63(1):193-195.

Hervet VAD, Laird RA, Floate KD (2016) A review of the McMorran diet for rearing Lepidoptera species with addition of a further 39 species. J Insect Sci 16(1):19.

Hirai Y, Legacion DM (1985) Improvement of the mass rearing techniques for the Asiatic corn borer, Ostrinia furnacalis (Guenee), in the Philippines. Jap Agric Res Quart 19(3):224-233.

Huettel MD (1976) Monitoring the quality of laboratoryreared insects: a biological and behavioral perspective. Environ Entomol 5(5):807-814.

Isa AL, Khadr GD (1973) Rearing of Ostrinia nubilalis Hbn. on artificial diets. Agric Res Rev (Cairo) 51(1):15-19.

Ishikawa Y, Takanashi T, Kim CG and others (1999) Ostrinia spp. in Japan: their host plants and sex pheromones. In: Proceedings of the 10th International Symposium on InsectPlant Relationships Springer, Dordrecht. p. 237-244.

Khomyakova VO (1871) [Factors influencing development, population and harmfulness of the European corn borer in steppe regions of Stavropol]. Autoref. Candidate Degree Thesis. Leningrad, All-Russian Plant Protection Institute (VIZR). 20 p. (In Russian)

Lassance JM (2010) Journey in the Ostrinia world: from pest to model in chemical ecology. J Chem Ecol 36(10):1155-116.

Lewis LC, Lynch RE (1969) Rearing the European corn borer, Ostrinia nubilalis (Hubner), on diets containing corn leaf and wheat germ. Iowa St J Sci 44(1):9-14.

Mihm JA (1985) Breeding for host plant resistance to maize stem-borers. Int J Trop Insect Sci 6(3):369-377.

Mutuura A Munroe E (1970) Taxonomy and distribution of the European corn borer and allied species: genus Ostrinia (Lepidopiera: Pyralidae). Mem Entomol Soc Can 102:1-112.

Nagy B (1970) Rearing of the European corn borer (Ostrinia nubilalis Hbn.) on a simplified artificial diet. Acta phytopathol acad sci hung 5(1):73-79.

Park JW, Boo KS (1993) An artificial diet and the rearing method for the Asian corn borer, Ostrinia furnacalis (Guenee)(Lepidoptera: Pyralidae). Korean J Appl Entomol 32(4):395-406. 
Patanakamjorn S, Guthrie WD, Young WR (1978) Meridic diets for rearing the tropical corn borer Ostrinia furnacalis. Iowa St J Res 52(4):361-370.

Qiao L, Zheng JW, Cheng WN and others (2008) Impact of 4 different artificial fodders on life span of Asian corn borer, Ostrinia furnacalis (Guenee). J Northwest A\&F Univ 36:109-112.

Rahayu T, Trisyono YA (2018) Fitness of Asian corn borer, Ostrinia furnacalis (Lepidoptera: Crambidae) reared in an artificial diet. J Asia-Pacific Entomol 21(3):823-828.

Rangdang Y, Jamormarn S, Granados G (1971) Mass rearing corn stem borer, Ostrinia furnacalis. In: Thailand National Corn and Sorghum Research Center (Faculty of Agriculture, Kasetsart University, Bankok) Annual Report. p. 264-266.

Reed GL, Showers WB, Huggans JL, Carter SW (1972) Improved procedures for mass rearing the European corn borer. J Econ Entomol 65(5):1472-1476.

Saito O, Nakayama I (1981) A simple rearing method for the oriental corn borer, Ostrinia furnacalis (Guenee) (Lepidoptera, Pyralidae). Bull Tohoku Nat Agric Exp Sta (Morioka) 63:243-247.

Salama HS (1970) Rearing the corn borer, Ostrinia nubilalis (Hubn.), on a semi-artificial diet. $Z$ angew Entomol 65(1-4):216-218.

Shapiro ID, Khrolinsky LG, Frolov AN and others (1980) [Methodical guidelines for assessment of host plant resistance in potato and maize of main pests]. L: VIZR. 138 p. (In Russian)

Вестник защиты растений 3(101) - 2019, с. 58-62

OECD+WoS: 1.06+IY (Entomology)

Singh P (1977) Artificial diets for insects, mites and spiders. IFI/Plenum Data Company, New York et al. 594 p.

Singh P, Moore RF (eds.) (1985) Handbook of insect rearing. Vol. I, viii +488 pp; Vol. II, viii +514 pp. Elsevier Science Publishers B.V., Amsterdam.

Tamarina NA(1990) [Fundamentals of Technical Entomology]. Moscow, Moscow University Publishing House. 202 p. (In Russian)

Wang Z, Lu X, He K, Zhou D (2000) Review of history, present situation and prospect of the Asian maize borer research in China. J Shenyang Agric Univ 31(5):402-412/

Win AT, Ishikawa Y (2015) Effects of diapause on postdiapause reproductive investment in the moth Ostrinia scapulalis. Entomol exp et appl 157(3):346-353.

Zhou DR, Ye ZH, Wang ZY (1992) Artificial rearing technique for Asian corn borer, Ostrinia furnacalis (Guenée) and its applications in pest management research. In: Advances in Insect Rearing for Research and Pest Management. Anderson TE, Leppla NC, eds. Boulder, San Francisco, Oxford: Westview Press; New Delhi, Bombay, Calcutta: Oxford \& IBH Publishing Co. Pvt. Ltd., p. 173-193.

Zhukovskaya MI, Selitskaya OG, Shchenikova AV and others (2017) [Interpopulation variation in the response of male European corn borers Ostrinia nubilalis Hbn. (Lepidoptera: Crambidae) to pheromone blends: an EAG study]. Journal of Evolutionary Biochemistry and Physiology 53(4):308310. (In Russian)

Zlotin AZ (1989) [Technical Entomology]. Kiev: Naukova Dumka. 183 p. (In Russian)

http://doi.org/10.31993/2308-6459-2019-3(101)-58-62

Мини-обзор

\title{
РАЗВЕДЕНИЕ ВИДОВ РОДА ОSTRINIA С ТРЕХЛОПАСТНЫМ УНКУСОМ САМЦОВ В ЛАБОРАТОРИИ ДЛЯ ЭКСПЕРИМЕНТАЛЬНЫХ ЦЕЛЕЙ
}

\author{
А.Н.Фролов*, М.Н.Берим, И.В.Грушевая \\ Всероссийский научно-исследовательский институт защиты растений, Санкт-Петербург
}

*Ответственный за переписку, е-mail: vizrspb@email.ru

Воспитание насекомых на искусственных питательных средах позволяет решать широкий круг энтомологических задач, причем за десятилетия, прошедшие после опубликования пионерской работы Дж. Боттджера (Bottger, 1942), посвященной разведению кукурузного мотылька Ostrinia nubilalis, было предложено множество рецептов сред, предназначенных как для лабораторного, так и массового разведения насекомых. На фоне краткого обзора мировой литературы, посвященной разведению вредных видов рода Ostrinia, подробно описаны приемы, используемые в ВИЗР для их разведения, в т.ч. приведен состав искусственной питательной среды на основе смеси зародышей пшеницы, соевой и кукурузной муки, которая позволяет выкармливать европейского кукурузного O. nubilalis, восточного кукурузного O. furnacalis и щетконогого O. scapulalis мотыльков. В статье описаны приемы разведения представителей рода Ostrinia, обеспечивающие получение живого материала разного генетического происхождения, который в экспериментах обнаруживает реакции, статистически неотличимые от таковых у природных особей.

Ключевые слова: стеблевой мотылек, искусственная питательная среда, разведение 